\title{
When the Ecofeminists Decide Product to Use: A Simple Analysis on Cloth Diapers Users
}

\author{
M.A. Sultan, R. Hurriyati, V. Aprianti* \\ Universitas Pendidikan Indonesia \\ Bandung, Indonesia \\ *vika.aprianti@unibi.ac.id
}

\begin{abstract}
Ecofeminist generation is closely related to ecology crisis which is caused by modernization and industrial civilization. Women who concern towards environment are striving in their daily life to keep earth save and a comfort place to be lived. It will be very interesting to analyze how their behavior to choose a product to be used. At the time when disposable diapers appear to be a practical solution to solve the problem in nursing the baby, ecofeminists prefer to use cloth diapers which is more nature friendly. It is, of course, not an easy preference regarding to the use of cloth diapers which needs more attempts. The aim of this research is to figure out some factors that influence the ecofeminists intention in preferring cloth diapers as a solution in nursing the baby. The technique of data analysis used was double regression analysis. The result of the research showed that product knowledge and perceived quality positively influence towards cloth diapers purchase intention.
\end{abstract}

Keywords-Ecofeminist; Consumer Behavior; Perceived Quality; Purchase Intention

\section{INTRODUCTION}

Why are women important in marketing? Apart from those women have a concern for nature or not, women are measured to have an important role to deter-mine the consumption. It has been shown that, for example, $70-80 \%$ purchase are made by women, $50 \%$ of advertisement is targeted for the women and $80 \%$ of TV advertisement are for the women [1]. In the future, a role of women who concern to nature becomes an enormous potential in marketing and its sustainability.

The consumers' shift behavior recently from anthropocentrism to ecocentrism and is famous to be called as "green movement" [2], and all ecofeminists who are a part of ecocentrist believe that humans relate one another and relate also to those other than humans, as nature. Un-fortunately, not every human realizes that relation-ship, there are ego and selfintention which are considered as important, and it is caused humans do violence one another and also nature. As a result, there is a lot of humanity tragedy and also ecology crisis. Ecology crisis which is happening recently can be reduced if we take a look of women's role and maximized it. Global warming which is caused by green-house gas, a flood which is caused by barren forest, and air pollution which is caused by the smoke fac-tory or motor vehicle is considered to be performed more by men or humans who tend to ignore the femininity which is full of affection.
The effort of environment rescue, regarding eco-feminists, is conducted by promoting the natures of women. Ecofeminism is not only struggling in tree planting action, but also a reflection of all environ-mental protection actions, children, spouse, a concern towards neighbor and the other.

Ecofeminism movement is believed to be one way to rescue ecology crisis which also has theologies legitimation. Ecofeminism can be a base of the living environment based on women. However, ecofeminism is not only for women. Ecofeminism is a philosophy which is based on a sustainability movement for the earth by emphasizing the aspects or natures of femininity. Men can also be considered to have ecofeminism view if he has affection for nature [3].

There are, actually, a lot of products that can be analyzed to figure out ecofeminism's behavior in using the product or service. Nevertheless, this simple analysis chooses cloth diapers (clodi) as the reflection of mothers who use the product to nurse their baby and indirectly it is believed to nurture the nature as well.

In Indonesia, the data of birthrate which is recorded in the Central Bureau of Statistic (CBS) be-comes big opportunities. Each year, birthrate increases with the average of $1.49 \%$. Until the end of 2015, the data recorded on the website bps.go.id showed the number of birthrate in Indonesia in the amount of $4,880,951$. The high increase of the birthrate be-comes a potential market segment of baby and baby under two-yearsold products and is very interesting to conduct. In the stage of under two years old baby, parents tend to spoil their baby by giving "the only" best quality product for their baby, particularly new mothers.

The use of Clodi can decrease disposable diapers waste which is believed to damage the environment because its difficulties to be unraveled by the micro-organism. It started from the little thing in the home environment but has the fatal effect on the ecological balance. If a home has a baby or toddler who still uses diapers, in a day the average of baby needs 3-6 disposable diapers. In a year, there will be 6 disposable diapers $\times 365$ days $=2190$ waste [4].

Modern cloth diapers exist and are socialized abroad since spouse Rick \& Erika Froese through Motherease which is the pioneer of cloth diapers in Canada in 1991. These cloth diapers get in Indonesia in 2008, as a local businessman to make local cloth diapers version [5]. 
The developing of Clodi is increasingly fast due to discussion forums in social media. There are discussion forums about cloth diaper through Facebook such as Komunitas Popok Kain (cloth diapers community), Penjual Pembeli Pecinta Popok Kain (Seller Buyer cloth diapers lover), Pasar Popok Kain (cloth diapers market) and Buat Popok Kain Yuk (let's make cloth diapers). However, Clodi is least known by the society, besides there is no big company which produces and markets the product in Indonesia with a suitable media, they also do not understand, do not have the opportunity to use the facility of various media to access the information.

[6] define purchase intention as consumer's tendency with identified purpose where it is usually measured in the real purchase. Further-more, [7] explain that purchase intention refers to the possibility of purchasing certain brand in product category at the time of purchasing. Nevertheless, the application of product purchase intention depends on several factors such as consumer interest and intention towards the product, social emphasis on the consumer from other person and general understanding of what is received. These factors can be explained based on the Theory of Reasoned Action (TRA) and Product Evaluation Model (PEM). TRA is proposed by [8] and widely used in the literature of consumer behavior and the study of purchase intention [9] [10] [11]. This theory assumes an individual motive to perform behavior as a function of the attitude towards behavior in a certain situation; the norm that ruled behavior in a certain situation and motivation to follow these norms (subjective norm). TRA is very instrumental and practical where an individual personally responsible for purchasing motive [12] [13].

However, some academics such as [14] believe that TRA may not truly ac-curate and the other academics like [15] state that the other external variable can be used to explain purchase intention. One of this variable is a value that is felt by the consumer which is clearly provided in PEM which is proposed by [16] and recently it is recorded as a constant factor in predicting purchase intention [17] [18]. This model con-siders purchase intention as a function of value that is felt and it also shows that consumer perception about quality and credibility initially influence the value that is felt. It then influences their evaluation towards purchase intention. It needs to be recorded that if a consumer does not maintain a good behavior on a product or ignores behavior norm, then they will not have a tendency to purchase a product. There-fore, we try to combine TRA and PEM to evaluate and predict consumer motive accurately [13]. In a simple way, the writers will study the influence of product knowledge and perceived quality towards purchase intention from the perspective of ecofeminists.

[19] [20] state that the amount of domain-specific knowledge about a product class which is kept in someone's memory is explained as product knowledge. This kind of knowledge, regarding [21], is directly dependent on the awareness or understanding of the given product among consumers, or over their confidence in it. [22] assumed that the quantity of product knowledge affects consumer's preference of product and brand. When involved in the process of purchasing a given product, the knowledge which the consumers have about the product will mark their pursuit behaviors, their processing of pertinent information, their decision making, and at last, and their purchase intentions. For instance, a practical study performed by [23] established that in terms of searching of per-tinent in-formation, the consumer's product knowledge has a substantial and positive effect on their struggles [24]. The literature ex-plained here proposes the following hypothesis for this study: H1: Product knowledge via cloth diaper positively affects consumers' purchase intentions.

Perceived quality is explained as consumers' decision about a product fineness or advantage. Assumed that consumer typically least of information or have only unequal information over that to base their decision, it is said that consumer belief may directly depend on the perceived quality of a product or brand, with that quality being seen as a key indicator among consumers. Assumed that it fundamentally consists of a collection of attributes connecting to consumer perception of the quality of a product or brand, perceived quality can intensify a positive word-of-mouth effect, lower consumer controlling costs, enhance price premiums, and increase purchase quantities. [25] assumed that when consumers perceived product quality as high, their perceived value of the product will be high too, thus increasing their purchase intentions [24]. In this enlightening, the writers propose the following hypothesis:

Perceived quality of a product via cloth diaper positively affects consumers purchase intentions.

Product knowledge and perceived quality via cloth diaper positively affect consumers purchase intentions.

\section{Methodology}

This research is a descriptive research with quantitative approach. Population in this research are group members of Cloth Diapers Community in Facebook which have 14.354 members when the research was conducted in May 2017. The sample used in this research are 118 people with purposive sampling technique or judgment sampling with the criteria of cloth diapers user community group member, they are diapers user, not the seller, they have been fulfilled the questionnaire in the determined time by the writers, that is two weeks. Only 118 members filled the questionnaire which is spread via online. The questionnaire spreading was using Google application form, it is conducted because the writers have the limitation of time and fund.

The questionnaire has been arranged through a validity and reliability test earlier. The collected data is then analyzed using double regression method using SPSS 23.00 for windows. To give the assurance that the regression equation has the accuracy in estimating, not biased and consistent, thus it is conducted classical assumption test early which consists of normality test, multicollinearity, and heteroscedasticity. The model used in this research modifies the developed model by [24]. F-test is used to figure out whether research regression model fits and is feasible to be used in the research, T-test is used to see the influence of independent variable towards dependent variable.

\section{RESULTS AND DISCUSSION}

Descriptive analysis was used to describe the sociodemographic profile of the respondents. 
Table 1. Respondents' profile.

\begin{tabular}{|l|l|l|l|}
\hline $\begin{array}{l}\text { Demographic } \\
\text { Characteristic }\end{array}$ & Data & $\begin{array}{l}\text { Frequency } \\
\mathbf{n = 1 1 8}\end{array}$ & $\mathbf{\%}$ \\
\hline Sex & Woman & 116 & 98 \\
\hline & Man & 2 & 2 \\
\hline Age & $\begin{array}{l}\text { Less than } \\
\text { 25 year }\end{array}$ & 23 & 19 \\
\hline & 26-30 year & 52 & 44 \\
\hline & above 31 year & 43 & 36 \\
\hline Latest Education & Senior high school & 62 & 53 \\
\hline & Bachelor & 44 & 37 \\
\hline & Master & 12 & 10 \\
\hline & Doctoral & 0 & 0 \\
\hline Occupation & Employee & 41 & 34 \\
\hline & Profesional & 0 & 0 \\
\hline & Entrepreneur & 8 & 7 \\
\hline & House Wife & 69 & 59 \\
\hline
\end{tabular}

It is seen from Table 1 above that the majority of the respondents are women in the amount of $98 \%$. The latest education is Senior High School in the amount of 53\%, the most occupation appear are housewife $59 \%$.

Classical assumption test result, normality test was using Kolmogorov-Smirnov analysis technique and the result was normal where Asymp Sig. value (0.74) greater than $\alpha$ (alpha) (0.05). Multi-collinearity was using SPSS program, by looking at the Variance Inflation Factor (VIF) value or tolerance (TOL) val-ue. The testing criteria were if Tol value $\geq 0.1$ or VIF value $\leq 10$, we obtain the product knowledge value and perceived quality was tolerance 0.654 , VIF 1.530 , it then concluded that the model was not mul-ti-collinearity.

Meanwhile, heteroscedasticity test using Glejser test showed that product knowledge variable has significant value $0.817>0.05$, and perceived quality variable has significant value $0.179>0.05$. It means that the correlation of two variables, independent with residual unstandardized did not have hetero-scedasticity problem on the regression model. And the result for double regression test:

$$
\mathrm{PI}=23.166+0.332 \mathrm{PK}+0.337 \mathrm{PQ}+\mathrm{e}
$$

It is then continued by correlation and determination test with the following summary:

Table 2. Summary model.

\begin{tabular}{|c|c|c|}
\hline R & R Square & Adjusted R Square \\
\hline 0.622 & 0.387 & 0.376 \\
\hline
\end{tabular}

Table 2 above shows double correlation coefficients between Product Knowledge (X1) and Perceived Quality (X2) with Purchase Intention (Y) or it is called as RY123 $=0.622$.

It showed that Product Knowledge (X1) and Perceived Quality (X2) simultaneously have a strong relationship with Purchase Intention (Y), it is be-cause RY123 value is on the interval 0.60-0.799 which states strong relationship. Meanwhile, the de-termination coefficient got was in the amount of $38.7 \%$.
Table 3. T-test and F-test result.

\begin{tabular}{|c|c|c|c|}
\hline \multicolumn{4}{|c|}{ t-test } \\
\hline Hypothesis 1 & $\begin{array}{c}\mathrm{t} \text { test }>\mathrm{t} \\
\text { table }\end{array}$ & $3.967>1.980$ & H1 Accepted \\
\hline Hypothesis 2 & $\begin{array}{c}\mathrm{t} \text { test }>\mathrm{t} \\
\text { table }\end{array}$ & $3.765>1.980$ & H2 Accepted \\
\hline \multicolumn{4}{|c|}{ F test } \\
\hline Hypothesis 3 & $\begin{array}{l}\text { F test }> \\
\text { F table }\end{array}$ & $36.317>3.08$ & H3 Accepted \\
\hline
\end{tabular}

It is seen, then, from table 3 above that $\mathrm{t}$-calculate value for Product Knowledge variable was 3.967. It means that $\mathrm{t}$ calculate is greater than t-table $(3.765>1.980)$, thus first hypothesis decision rejected $\mathrm{H} 01$ and accepted $\mathrm{H} 1$ which explains that Product Knowledge influences towards Purchase Intention, thus the writers' first hypothesis is accepted. The empirical results for $\mathrm{H} 1$ were consistent with those obtained by [19]; specifically, the extent of consumer knowledge about cloth diapers (such as functions and method of use) influences consumers' purchase intentions. Creating a stronger impression on consumers might help to increase consumers' purchase intentions for a company's products [24]. T-calculate value for the Perceived Quality variable is 3.765 . It means that $t-$ calculate is greater than t-table $(3.765>1.980)$, thus the first hypothesis decision rejected $\mathrm{H} 02$ and accepted H2 which explains that Perceived Quality influences towards Purchase Intention, thus the second hypothesis which is proposed by the writers is also accepted. F-calculate value is in the amount of 36.317 , it means that F-calculate value is greater than the Ftable value $(36.317>3.08)$, thus hypothesis decision rejected $\mathrm{H} 0$ and accepted $\mathrm{H} 3$ which means that Product Knowledge and Perceived Quality influence at the same time towards Purchase Intention, thus the third hypothesis that the writers proposed is accepted.

Theory of reasoned action which is proposed by [26], has been used for two decades ago to analyze shared interest and behavior. [26] theory reasoned action assumes that behavior is determined by individual interest to do or not to do a certain behavior or vice versa. Interest is determined by two independent variables including attitude and subjective norm.

[26] in "theory of reasoned action" state that subjective norm is the de-termination of behavioral interest. Subjective norm is individual belief function in agreeing or disagreeing with a certain behavior. Agreeing and disagreeing certain behavior are based on a belief which is called normative belief. Family environment factor is someone who can influence individual action, an individual will behave if another perception towards that behavior tends to be positive. The individual perceives that individual behavior is allowed or vice versa, not allowed.

Through this TRA theory, the writers are translating ecofeminists' behavior. This research may give a few descriptions of the result. How is the product knowledge seen 
to strengthen the subjective norm which is the determination of behavior's action? Ecofeminists which is represented by cloth diapers consumer believe that, in nursing their baby, they cannot damage the surrounding environment because they directly love the nature and indirectly they want their ascendants live sustainably on peace earth.

It is then, by way of perceived quality, seen that it positively influences towards purchase intention, ecofeminists are confirmed that they will do the best in preferring the product they used, it can be seen that ecofeminists give attention to the performance quality, excellence, superiority, durability, suitable quality and the style of a product.

There are three interesting things in which we can see from this research. The first, the dependent variable which is taken and is believed influence purchase intention of cloth diapers product in this re-search is one of the market strategies to influence consumers' thought to buy a product. Cognition process in diaper purchasing is closely relating to perception and preference. It can be caused by the consideration that it is not the mother who uses the diapers, thus environment role to give the knowledge is the first step. Product knowledge and perceived quality are the reflections of cognition proses which have been through by mothers.

The second interesting thing is, talking about eco-feminists nowadays is not always about women. It is taken from demographic data that there are $2 \%$ of the respondents which use cloth diapers have male sex. Although it is only a few percentages it is sufficient to give a description that feminism is not only talking about women physically, but it has a wider talk about aspects or femininity values. Men also can be said to have ecofeminist view if he has affection for nature.

The third, the contribution of dependent variable product knowledge and perceived quality only influence Clodi product purchase intention in the amount of $38.7 \%$. It needs to be analyzed about the other variable which may influence greater towards this purchase intention.

\section{CONCLUSION}

As a combined movement between ecology and feminism, ecofeminism is not only collecting the essence of feminism theoretical, but it also has to ab-sorb ecology perspective theoretically. Based on the integrity of these theories and multidimension perspective form this theory, ecofeminism commits to criticized modern industrial civilization and tries to rebuild society cultural values to achieve women and nature freedom.

It is explained by [2] about something that relates to marketing and women oppression, they state that many specific in-stances from anthropocentric from marketing field. The first, marketing has been played in a dominant issue such as women who are being objected to in western, selling beauty myth. The second is marketing segmentation, the variable of religion, racist, nation, age, and sex which are used to segment the market can lead to promotion and strengthen stereo-type in marketing communication strategy. The third, materialism, consumption, identity expression which are stimulated by the company, are successful individual demonstrative in a market economy. The fourth is the packaging. The packaging which is widely used by the company as a means of promotion to sell the product. A high level of consumer's prosperity makes consumer are brave to pay higher to achieve comfort, appearance, dependency, and pres-tige from a better package, but the company does not consider resource depletion on earth and nature destruction. The fifth, consumption, goods and service promotion in several cases caused "compulsive" consumption" and "addictive", which mainly influence women marketing has contributed to this case by actively institutionalized that behavior in consumer's lifestyle. The sixth, nature destruction, as well as the bad effect of war towards the living environment. The last, marketing role in wealth distribution which is uneven, it belongs to marketing politics, individual health care, utility privatization, wealth for the minority [27].

Even though the article was published twenty years ago, but there are some relevant points to the current situation. However, the increasing of human consciousness which is supported by the ease of in-formation which is believed will help the process of anthropocentric changing to ecocentrist which consist of green movement and ecofeminism inside.

The research is far away from expected research; we can see how ecofeminist consumer behavior role in consumption action. It needs a deep and more serious analysis. Further research can explore the various theory of consumer behavior, many field survey and the technique to determine someone's classification criteria which are called as ecofeminist of marketing filed.

\section{REFERENCES}

[1] Dougary, G. 1994. The executive tart and other myths: Media women talk back. London: Virago Press.

[2] McDonagh, P. \& Prothero, A. 1997. Leap-frog marketing: the contribution of ecofeminist thought to the world of patriar-chal marketing. Marketing Intelligence \& Planning, 15(7): 361-368.

[3] Pertiwi, C. 2012. Jurnal sosial dan politik perempuan yang dilacurkan. Journal Unair.

[4] Puspita, S. 2012. Popok Kain Modern, Jakarta: Halamanmoeka.

[5] Alimah, N.T.F. 2014. Ensiklopedia Clodi. Yogyakarta: Leutikaprio.

[6] Young Kim, E. \& Kim, Y.K. 2004. Predicting online purchase intentions for clothing products. European journal of Marketing, 38(7): 883-897.

[7] Crosno, J.L., Freling, T.H. \& Skinner, S.J. 2009. Does brand social power mean market might? Exploring the influence of brand social power on brand evaluations. Psychology \& marketing, 26(2): 91-121.

[8] Fishbein, M. \& Ajzen, I. 1975. Belief, attitude, intention and behavior: An introduction to theory and research.

[9] Botha, N. \& Atkins, K. 2005. An assessment of five different theoretical frameworks to study the uptake of innovations. New Zealand Agricultural and Resource Economics Society: 26-27.

[10] Beadnell, B., Baker, S.A., Gillmore, M.R., Morrison, D.M., Huang, B. \& Stielstra, S. 2008. The Theory of Reasoned Action and the Role of External Factors on Heterosexual Men's Monogamy and Condom Use 1. Journal of Applied Social Psychology, 38(1): 97-134.

[11] Alsughayir, A. \& Albarq, A.N. 2013. Examining a theory of reasoned action (TRA) in internet banking using SEM among Saudi consumer. International Journal of Marketing Practices, 1(1): 16-30.

[12] Hakkak, M., Vahdati, H. \& Nejad, S.H.M. 2015. Study the role of customer-based brand equity in the brand personality effect on purchase intention. International Journal of Asian Social Science, 5(7): 369-381.

[13] Vahdati, H. \& Nejad, S.H.M. 2016. Brand Personality Toward Customer Purchase Intention: the Intermediate role of elec-tronic word-of-mouth and brand equity. Asian Academy of Management Journal, 21(2), 1-26. 
[21] Lin, L.Y. \& Zhen, J.H. 2005. Extrinsic product performance signaling, product knowledge and customer satisfaction: an integrated analysis-an example of notebook consumer be-havior in Taipei city. Fu Jen Management Review, 12(1): 65-91.

[22] Coulter, R.A. Price, L.L. Feick, L. \& Micu, C. 2005. The evolu-tion of consumer knowledge and sources of information: Hungary in transition. Journal of the Academy of Market-ing Science, 33(4): 604-619.

[23] Han, T.I. \& Stoel, L. 2016. The effect of social norms and product knowledge on purchase of organic cotton and fair-trade apparel. Journal of Global Fashion Marketing, 7(2): 89-102.

[24] Chen, H.S., Tsai, B.K. \& Hsieh, C.M. 2017. Determinants of consumers' purchasing intentions for the hydrogen-electric motorcycle. Sustainability, 9(8): 1447.

[25] Tamimi, N. \& Sebastianelli, R. 2016. How e-tailing attributes affect perceived quality: The potential impact of customer demographics and online behaviors. The TQM Journal, 28(4), 547-560.

[26] Ajzen, I. \& Fishbein, M. 1980. Understanding attitudes and predicting social behaviour. New Jersey: Prentice-Hall.

[27] Dixon, D.F. 1992. Consumer sovereignty, democracy, and the marketing concept: a macro marketing perspective. Cana-dian Journal of $\begin{array}{lll}\text { Administrative } & \text { Sciences, } & \text { 9(2): }\end{array}$ 